\title{
Penanggulangan Bullying dalam Pembetukan Karakter Peserta Didik di MI Muhammadiyah PK Bendo, Boyolali
}

\author{
Achmad Muthali' in ${ }^{1}$, Nurhidayat ${ }^{2}$, Sri Handayani A.L ${ }^{3}$, Maryadi ${ }^{4}$, Kiki Nirmala Sari ${ }^{5}$, Ilya Wahyu Al \\ Haniyah $^{6}$, Kharis Nur Ulfa ${ }^{7}$, Rizka Mafida Feby Firdareza ${ }^{8}$, Khusnul Maulidiya ${ }^{9}$, Eni Ratnasari ${ }^{10}$, \\ NF. Andaruningtyas ${ }^{11}$

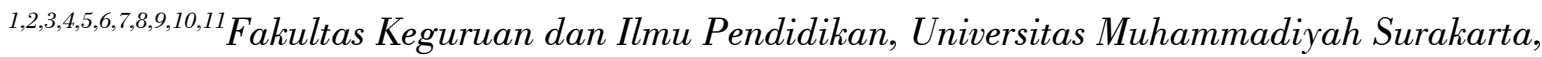 \\ Indonesia
}

\section{INFORMASI ARTIKEL}

\begin{tabular}{l} 
Histori Artikel: \\
Submit: 28 April 2020 \\
Revisi: 30 Agustus 2020 \\
Diterima: 1 September 2020 \\
Publikasi: 3 September 2020 \\
Periode Terbit: Desember 2020 \\
\hline Kata Kunci: \\
bullying, \\
fisik, \\
pembentukan karakter, \\
psikologi, \\
verbal
\end{tabular}

\section{Correspondent Author:}

Achmad Muthali'in

Fakultas Keguruan dan Ilmu Pendidikan

Universitas Muhammadiyah Surakarta,

Indonesia

Email: achmad.mutholiin@ums.ac.id

\begin{abstract}
ABSTRAK
Artikel ini bertujuan untuk menginformasikan kegiatan pengabdian masyarakat terkait identifikasi dan sosialisasi tentang jenis dan tindakan bullying terhadap anak usia dini pada seluruh siswa MI Muhammadiyah Bendo PK Kabupaten Boyolali. Kasus Bullying sering terjadi di lingkungan sekolah maupun luar sekolah bahkan sudah menjadi budaya yang dianggap sepele, padahal kasus ini memiliki resiko yang tentunya berdampak buruk pada korban, pelaku serta orang-orang sekitar. Bentuk umum yang terjadi pada kasus bullying di sekolah adalah verbal, fisik, dan psikologi. Kegiatan ini berdasar data siswa siswi MI Muhammadiyah Bendo PK Kabupaten Boyolali kelas I (satu) sampai VI (enam) yang berjumlah 150 orang. Pengabdian ini diawali dengan kajian sederhana menggunakan pendekatan kualitatif dengan bentuk deskriptif dan observasi, serta didukung dengan teknik Wawancara dan Dokumentasi. Selanjutnya dilakukan diseminasi kepada stakeholder yang ada di MI Muhamamdiyah Bendo PK sebagai tindak lanjut kegiatan pengabdian.
\end{abstract}

\section{Pendahuluan}

Peraturan Kementeri Pendidikan Nasional No. 23

Tahun 2006 menyatakan bahwa "pendidikan dasar memiliki tujuan untuk meletakkan dan mengembangkan dasar kecerdasan, pengetahuan, kepribadian, akhlak yang mulia serta mempunyai keterampilan untuk hidup mandiri, dan melanjutkan pendidikan ke jenjang yang lebih tinggi". Hal ini berarti sekolah dasar merupakan pendidikan wajib, formal dan jenjang pendidikan paling awal yang memiliki peranan untuk pendidikan selanjutnya. Ketentuan tersebut merupakan penegasan Undang-Undang No. 20 Tahun 2003 tentang Sisdiknas, Pasal 3 menyatakan bahwa: Pendidikan Nasional berperan penting dalam mengembangkan kemampuan peserta didik dan membentuk watak serta peradaban Bangsa yang bermartabat dalam rangka mencerdaskan anak bangsa dalam kehidupan bangsa, yang bertujuan untuk mengembangkan potensi peserta didik agar tumbuh menjadi manusia yang beriman dan bertakwa kepada Tuhan Yang Maha Esa, sehat, berakhlak mulia, berilmu, cakap, kreatif, dan menjadi warga negara yang demokratis serta bertanggung jawab.

Ketentuan dalam Permendiknas dan Sisdiknas di atas menegaskan bahwa pendidikan di sekolah berperan penting dalam pembentukan karakter peserta didik. Karenanya lingkungan sekolah berikut interaksi antar semua warga sekolah, harus mendukung berkembang dan terbentuknya karakter positif peserta didik.

Peran sekolah sebagai bagian penting pembentukan karakter dikemukakan oleh Ki Hajar Dewantara 
(2011:139-140), ada tiga peranan besar yang mempengaruhi perilaku dan kepribadian anak tentang lingkungan pendidikan. Lingkungan pendidikan ini biasa dikenal dengan sebutan "Tripusat pendidikan ada tiga bagian yaitu: 1) Pendidikan dilingkungan keluarga, 2) Pendidikan di lingkungan sekolah, dan 3) Pendidikan yang ada di lingkungan masyarakat. Melalui jenjang sekolah yang ada didaerahnya, peserta didik dipersiapkan sejak dini untuk menjadi seorang yang memiliki kepribadian yang positif, baik, kreatif, inovatif dll. Peserta didik tidak hanya dididik untuk menjadi pintar dan menjadi warga sekolah yang baik tetapi juga menjadi warga masyarakat yang bisa menjadi panutan untuk lebih baik.

Karenanya Kementrian Pendidikan dan Kebudayaan sejak tahun 2001 memrogramkan penguatan 18 karakter di sekolah. Meliputi karakter religius, jujur, toleransi, disiplin, kerja keras, kreatif, mandiri, rasa ingin tahu, semangat kebangsaan, cinta tanah air, menghargai prestasi, komunikatif, cinta damai, gemar membaca, perduli lingkungan, perdulil sosial, dan tanggung jawab. Seluruh jenjang sekolah harus melaksanakan pendidikan berkarakter tersebut dalam proses pendidikannya.

Idealnya jika program pendidikan karakter yang dicanangkan oleh Kementrian Pendidikan dan Kebudayaan di atas, yang sudah berlangsung hampir dua dekade, berjalan baik, mestinya karakter peserta didik yang tidak selaras dengan 18 karakter di atas, akan sangat berkurang. Namun faktanya memperlihatkan fenomena sebaliknya dari karakter toleransi, cinta damai, dan perdulil sosial. Karakter negative tersebut salah satunya Bullying atau kekerasan terhadap teman sebayanya.

Bullying atau dalam bahasa Indonesia dikenal dengan perundungan adalah tindakan atau prilaku berlebihan atau distruktif yang dilakukan oleh siswa terhadap siswa yang lain. Bullying di kalangan pelajar tidak hanya menurunkan prestasi akademiknya tetapi juga bisa menyebabkan gangguan kesehatan mental dan cedera fisik. Penindasan yang berupa pelecehan dapat mengakibatkan gangguan mental sementara penganiayaan dapat mengakibatkan cedera fisik dan ini dapat berulang-ulang terjadi. [Jan, 2015]. Dalam beberapa kasus bahkan bisa mengakibatkan kematian.

Hal ini sesuai dengan pendapat Prasetyo bahwa bullying adalah bentuk perilaku agresif yang dapat dilakukan oleh siapa saja dan biasanya dalam bentuk penindasan dan kekerasan, kepada orang-orang atau kelompok masyarakat lain yang dilakukan secara berulang-ulang dengan cara menyakiti secara fisik maupun non fisik bisa menggangu mental anak tersebut (Prasetyo, 2011).

Kasus bullying yang mengakibatkan gangguan mental bisa berakibat fatal bagi sorang anak. Hasil penelitian Zakiyah, dkk (2017), memperlihatkan hal itu. Bullying dialami seorang remaja 15 tahun di Denpasar, Bali. Karena di-Bully, Dia tega membunuh temannya sendiri karena dendamnya kepada korban. Pelaku mengaku kerap menjadi target Bullying korban sejak kelas satu SMP. Bahkan penelitian Indrayani (2019), hampir semua siswa melakukan Bullying, bentuknya Bullying verbal. Di samping bentuk Bullying yang lain, seperti Bullying fisik, Bullying sosial, dan Bullying elektronik. Semuanya berdampaak buruk pada karakter korban (Wulandari, 2017)

Bullying berdamak buruk bagi korban. Penelitian Novalia (2016) menegaskan hal itu. Bullying menimbulkan dampak negative terhadap korban. Anak korban Bullying bersikap anti sosial terhadap lingkungan bermainnya, korban menarik diri dari ingkungan sosialnya. Menjadi acuh tak acuh terhadap apa yang terjadi dilingkungannya. Secarai psikolgis, korban menjadi depresi. Bermula dari trauma, kemudian berubah menjadi depresi.

Berdasarkan fenomena di atas, menarik untuk mengkaji Bullying di sekoah, khusunya mengeai dampaknya pada karakter peserta didik. Rangsangannya lagi di lakukan di MI Muhammadiyah Program Khusus dengan visi misi karakter keislaman yang kuat. Menjadi pendorong kuat untuk meneliti hal tersebut.

Peserta didik MI, sebagaimana jenjang sekolahnya, umumnya berusia seperti usia siswa sekolah dasar. Anak atau siwa seusia ini, ketika berinteraksi dan berkomunikasi dengan teman sekolah dan teman yang ada di sekitar rumah, terkadang sering mempunyai permasalahan dan konflik. Beberapa anak pernah melakukan kekerasan sebagai salah satu cara untuk membuktikan bahwa peserta didik bisa masuk dalam kelompok tertentu, meskipun anak sendiri merasa belum nyaman dengan perilaku diri sendiri tersebut. Beberapa studi prevalensi menunjukkan bahwa kekerasan adalah masalah umum di SD kelas Sekolah Menengah (Jansen, 2012). Di sekolah ada 3 karakteristik bullying yang pertama, tindakan yang disengaja untuk menyakiti korban, kedua, tindakan yang dilakukan dengan cara tidak seimbang sehingga anak menimbulkan rasa tertekan dan ketiga, tindakan yang 
dilakukan secara terus menerus tanpa ada rasa salah sedikit pun (Astuti, 2013).

Bentuk intimidasi yang paling umum dan sering menurut Owen adalah; penghinaan, panggilan nama dan julukan, pemukulan, penyerangan langsung, pencurian, ancaman, dan pengucilan atau isolasi sosial (Owens et al.,2000). Temuan penelitian Crick \& Grotpeter (1995) juga menegaskan bahwa diantara bentuk bullying adalah memukul, bentuk pelecehan verbal, ancaman gerak tubuh, dan perusakan properti dianggap sebagai bentuk utama penindasan. Smith et al. (2002), juga memiliki pandangan yang sama tentang bentuk bullying dan mereka menambahkan rumor, pengecualian dari permainan, panggilan nama, dan meletakkan, sebagai bentuk utama dari bullying verbal.

Kegiatan ini diawali dengan kajian sederhana menggunakan pendekatan kualitatif dengan bentuk deskriptif dan menggunakan Observasi, serta didukung dengan teknik Wawancara dan Dokumentasi. Tim melakukan pengambilan data pada siswa yang dipilih secara acak dengan perwakilan setiap kelas 2 siswa yang akan di wawancarai. Berdasarkan observasi dan wawancara dengan siswa yang sudah dipilih acak setiap kelasnya pada peserta didik MI Muhammadiyah Bendo Kabupaten Boyolali, perilaku yang sering menyimpang yang sering dilakukan siswa, yaitu dalam bentuk: (1) siswa sering melakukan perilaku School Bullying terhadap temannya, (2) siswa sering berbicara kurang sopan terhadap temannya, (3) kurangnya pemantauan dan tindak lanjut dari guru untuk mengatasi bullying di kelas.

Berdasarkan wawancara dan hasil observasi kami ke dalam kelas yang dilakukan oleh tim pada Senin, $17-$ 21 Februari 2020 di MI Muhammadiyah Bendo PK Kabupaten Boyolali, ditemukan beberapa perilaku yang menyimpang dilakukan oleh peserta didik terhadap temannya. Peserta didik melakukan perilaku Bullying/kekerasan terhadap teman sebayanya pada saat disekolah. Beberapa siswa melakukan bullying terhadap temannya secara verbal, fisik, penindasan sosial bahkan beberapa ada yang melakukan penindasan seksual. Penindasan verbal tampak pada beberapa kejadian seperti: siswa mengolok-olok dan mengancam, perlakuan penindasan ini sangat sering dilakukan oleh siswa yang membully dengan alasan bercanda dan ingin memuaskan diri. Penindasan secara langsung atau fisik ditemukan ada beberapa kejadian kasus seperti: peserta didik mendorong, memukul, menarik, dengan kasar dan sengaja, menendang, bentuk penindasan ini juga sering dilakukan baik dilakukan secara tidak sengaja atau karena benarbenar ingin melakukannya. Bullying Sosial juga dilakukan nampak pada beberapa kejadian seperti: meninggalkan temannya sendirian, memfitnah, mengatakan pada teman yang lain untuk tidak berteman dengan yang di bully serta mempermalukan temannya di depan umum. Penindasan seksual juga pernah dilakukan oleh beberapa siswa dalam bentuk menulis perkataan kotor kemudian ditunjukkan pada teman yang ingin di bully bahkan sampai dengan memegang kelamin temannya, hal ini di lakukan oleh teman sesama jenis kelamin. Perlakuan itu dijadikan sebagai bahan bercanda.

\section{Metode Pelaksanaan}

Kegiatan pengabdian ini diawali dengan kajian sederhana menggunakan pendekatan kualitasi. Meolong (2011: 6) pendekatan kualitatif yang dimaksud adalah suatu bentuk pemahaman tentang fenomena subjek yang dialami oleh peneliti bolistik dan dengan cara deskriptif dalam bentuk bahasa, dan bentuk kata-kata pada suatu konteks/kalimat khusus yang alamiah dan dengan memanfaatkan berbagai metode alamiah. Kajian awal merupakan kajian deskriptif yang mengacu atau menyelidiki pada suatu keadaan, kondisi, peristiwa, dan situasi kegiatan yang hasilnya akan disampaikan dalam bentuk sebuah laporan penelitian. Tempat pelaksanaan penngabdian ini adalah MI Muhammadiyah Bendo PK Kabupaten Boyolali, dengan berdasar pada kajian awal terhadap siswa kelas 1 sampai 6 dengan jumlah 150 peserta didik. Tim pengabdian sebelumnya memilih secara acak dengan perwakilan setiap kelas 2 siswa yang akan di wawancarai. Berdasarkan observasi dan wawancara dengan siswa yang sudah dipilih acak setiap kelasnya pada peserta didik MI Muhammadiyah Bendo Kabupaten Boyolali, perilaku yang menyimpang dilakukan siswa di sekolah, yaitu: (1) peserta didik sering melakukan perilaku School Bullying terhadap temannya, (2) peserta didik sering berbicara tidak patut dicontoh terhadap temannya, (3) kurangnya pemantauan dan tindak lanjut dari guru untuk mengatasi bullying di kelas.

Untuk mendapatkan data yang akurat tim melakukan instrumen yaitu sebagai berikut:

\section{Observasi ke dalam kelas}

Observasi merupakan suatu cara untuk mengumpulkan data dengan menggunakan pengamatan 
e-ISSN 2716-0327

doi: 10.23917/bkkndik.v2i2.10784

dan pencatatan secara sistematik pada suatu fenomena atau gejala yang ada (Arikunto, 2010:133). Data yang diperoleh dikumpulkan berkaitan dengan dampak-dampak Bullying.

\section{Wawancara}

Sugiyono (2010:194), berpendapat bahwa wawancara yang digunakan sebagai teknik pengumpulan data, agar data yang diperoleh akurat untuk menemukan permasalahan yang ada disekolah.

Wawancara menggunakan beberapa pertanyaan yang telah disiapkan untuk membantu dan mengetahui alasan alasan korban dan pelaku bullying yang berkaitan dengan dampak-dampak Bullying.

\section{Dokumentasi}

Dokumentasi seperti pengambilan gambar gambar tertentu yang berkaitan dilakukan untuk memperoleh data (Hamidi, 2004:72). Metode ini digunakan untuk bahan diseminasi.

\section{Hasil Pelaksanaan dan Pembahasan}

Sebagai bahan diseminasi tim kami pada Senin, 17-21 Februari 2020 di MI Muhammadiyah Bendo PK Kabupaten Boyolali, menemukan ada beberapa perilaku yang menyimpang yang dilakukan oleh peserta didik terhadap temannya. Peserta didik sering melakukan perilaku kekerasan/bulliying ke teman kelasnya dan bahkan dengan kelas lainnya. Beberapa siswa melakukan perilaku bullying terhadap temannya secara verbal, fisik, penindasan sosial bahkan beberapa ada yang melakukan penindasan seksual. Penindasan verbal tampak pada beberapa kejadian seperti: siswa mengolok-olok dan mengancam, perlakuan penindasan ini sangat sering dilakukan oleh siswa yang membully dengan alasan bercanda dan ingin memuaskan diri. Penindasan fisik ditemukan pada beberapa kejadian seperti: siswa mendorong, mencubit, menarik dengan kasar dan sengaja, memukul dan menendang, bentuk penindasan ini juga sering dilakukan baik dilakukan secara tidak sengaja atau karena benar-benar ingin melakukannya. Bullying Sosial juga dilakukan nampak pada beberapa kejadian seperti: meninggalkan temannya sendirian, memfitnah, mengatakan pada teman yang lain untuk tidak berteman dengan yang di bully serta mempermalukan temanya di depan umum. Penindasan seksual juga pernah dilakukan oleh beberapa siswa dalam bentuk menulis perkataan kotor kemudian ditunjukkan pada teman yang ingin di bully bahkan sampai dengan memegang kelamin temannya, hal ini di lakukan oleh teman sesama jenis kelamin. Perlakuan itu dijadikan sebagai bahan bercanda.

Untuk memperkuat dan menambah bahan diseminasi penggalian informasi dilakukan pada seluruh siswa MI Muhammadiyah PK Bendo Kabupaten Boyolali Kelas I (satu) sampai kelas VI (enam) dengan jumlah peserta 150 orang. Setiap kelas dipilih secara acak sebanyak 2 siswa untuk dilakukan wawancara perihal Bullying. Hasil wawancara menunjukkan bahwa dari ke enam kelas terdapat masing-masing 2-3 orang yang sering melakukan perilaku menyimpang yaitu Bullying. Ditemukan hasil bahwa penyebab perilaku Bullying adalah faktor internal siswa yaitu faktor orang tua broken home dan kurang perhatian dari kedua orang tuanya masing-masing.

\section{Broken Home}

Kasus ini juga menjadi salah satu alasan terbesar kenapa anak-anak melakukan kegiatan menyimpang pada temannya. Siswa yang mengalami hal tersebut cenderung mendapat tekanan emosional tidak teratur dengan usia yang belum siap untuk mengalaminya. Dampaknya, siswa akan mengalami atau melakukan penyimpangan seperti yang dilihat apabila tidak dikontrol oleh keluarga, terutama orang tua. Seorang anak sering melihat orang tuanya bertengkar, akan merubah mindset yang awalnya pertengkaran itu adalah hal yang tidak boleh dilakukan menjadi hal biasa, sehingga ketika dalam lingkungan luar keluarga akan berperilaku yang sama seperti yang dilakukan keluarganya.

\section{Kurang perhatian}

Hal ini terjadi pada anak yang memiliki keluarga pekerja yang bekerja dari pagi hingga larut malam. Seorang anak sangat membutuhkan perhatian khusus oleh keluarga terutama orang tua, namun karena sudah merasa capek orang tua kadang melupakan tanggung jawabnya, yang dipikirkan orang tua adalah agar anak-anaknya bisa sekolah, makan yang cukup dan terpenuhi kebutuhannya. Pada dasarnya seorang manusia lebih membutuhkan perhatian batin yaitu dimana para orang tua memberikan pelukan, nasihat, candaan yang berkaitan dengan kehangatan keluarganya. Dampak dari kejadian ini adalah anak yang mengalami kurangnya perhatian dari orang tua akan mencari perhatian dari orang baru yang ada disekelilingnya misalnya disekolah. Anak-anak akan meminta 
perhatiana dari guru atau teman-temannya baik dengan cara wajar atau tidak.

Dampak-dampak Bullying yang terjadi pada orang yang di Bully dan yang mem-bully pada siswa MI Muhammadiyah Bendo PK Kabupaten Boyolali ialah sebagai berikut:

\section{a. Dampak bagi korban Bullying.}

Menurut Sthephenson dan Smith (Trevi 2010) ada bebrapa ciri bullying, diantaranya (a) korban cenderung pasif, memiliki sifat terlalu yang cemas dan kepercayaan diri yang sangat rendah, korban merasa dirinya lemah, kalah, dan tidak berdaya serta merasa tidak mampu untuk menjaga dirinya, mereka cenderung diselimuti rasa takut. (b) rasa korban yang proaktif cenderung memiliki sifat lebih kuat secara fisiknya dan lebih aktif dibanding dengan korban yang pasif. (c) peseta didik yang menjadi korban diprovokasi cenderung melakukan tindakan balik bulliying ke temannya karena ada unsur paksaan. Tidak bisa dipungkiri perilaku menyimpang ini bisa mengakibatkan luka psikologis atau trauma yang sangat mengaggangu bagi korban. Pertama, bullying membuat korban merasa sedih, kesepian, tidak bahagia, dan ketakutan yang luar biasa. Bullying juga membuat rasa kita tidak aman, kepercayaan diri kita hilang, berpikir rendah diri dan merasa bersalah dihadapan mereka, memiliki dendam dan tanpa mereka sadari dendam tersebut terbalaskan pada temannya yang lain, bahkan sampai ada yang tidak ingin sekolah dan pindah dari sekolah mereka yang sekarang karena merasa terancam dan tidak bebas. Bahkan dalam beberapa kajian menunjukkan bahwa tindakan bullying bisa berdampak hingga dewasa, sebagaimana disampaikan oleh Smit \& Scherman (2016) bahwa bullying memiliki dampak sosial yang luas, dan banyak orang dewasa mengalami bekas bullying pada masa mereka masih kanak-kanak. Pandangan ini didukung oleh Brimblecombe, Evans-Lacko, Knapp, King, Takizawa, Maugham dan Arseneault (2018), yang menyatakan bahwa bullying terkait erat dengan masalah kesehatan mental seseorang di masa kanak-kanak yang kemudian berlanjut hingga seseorang menjadi dewasa.

\section{b. Dampak bagi pelaku bullying}

Menurut Sthephenson dan Smith (Trevi,2010), ada tiga tipe dari pelaku bulliying, yaitu: (a) pelaku mempunyai rasa percaya diri bahwa dirinya paling kuat, menyukai kekerasan, selalu memiliki rasa aman dan popularitas yang sangat tinggi. (b) Pelaku biasanya memiliki rasa cemas dan lemah dalam hal nilai akademik, namun ingin merasa dirinya paling benar. (c) Pelaku biasanya juga korban bullying dan mengincar korban dalam situasi tertentu. Ini selaras dengan temuan Haynie dkk. (2001), yang mengungkapkan bahwa ada siklus bullying di mana pelaku intimidasi dan korban mengubah peran mereka. Kadang-kadang pelaku intimidasi dapat menjadi korban dan seringkali korban dapat bertindak sebagai pelaku intimidasi pada kesempatan lain. Sebagaimana juga Ma (2001), menyebutkan bahwa siklus bullying terlihat jelas dalam berbagai aspek kehidupan sosial dan kehidupan di sekolah.

Dampak dari kegiatan menyimpang ini bukan hanya bagi korban saja namun juga pada yang melakukan hal tersebut. Pertama, jika dibiarkan atau tidak ditindaklanjuti dengan benar Pelaku bullying tidak akan merubah sikapnya bahkan semakin agresif. Pelaku di usia dini rentan terhadap masalah psikologi yang berkepanjangan dan perilaku tersebut jika tidak segera ditangani dengan cepat dan tepat akan berresiko menjadikan anak pada waktu remaja tidak bahagia, karena masa lalu yang tidak baik serta akan dijauhi oleh teman-teman yang baik dikarenakan takut untuk berteman.

\section{Simpulan}

Bullying dilakukan dalam 4 bantuk diantaranya adalah secara Verbal. Bullying ini merupakan bentuk tak tak kasat mata dan tidak menimbulkan luka fisik pada korban namun dapat melukai hati seseorang. Bullying berbentuk Fisik. Cara ini berbentuk memukul, mencubit, mendorong, menendang dan sesuatu yang bersentuhan secara langsung pada tubuh korban, perlakuan ini sering dilakakukan oleh siswa laki-laki untuk menunjukkan kehebatannya, namun tidak disadari bahwa perilaku itu merupakan hal yang tidak baik bagi pelaku dan korban. Bullying Penindasan sosial. Bullying ini berbentuk olokolokan, ancaman sehingga korban merasa terintimidasi terkucilkan dan takut pada pelaku. Bullying selanjutnya ialah penindasan Seksual. Bentuk penindasan ini berupa menulis atau menggambar organ intik korban bahkan sampai dengan menyentuh baik disengaja maupun tidak. 4 bentuk bullying tersebut merupakan jenis Bullying yang sangat sering kita jumpai di lingkungan sekolah baik dari tingkatan PAUD sampai dengan tingkatan SMA yang setiap tahunnya terus bertambah. 
e-ISSN 2716-0327

doi: 10.23917/bkkndik.v2i2.10784

Dampak Bullying sangat besar baik bagi korban maupun pelaku. Adapun dampak bagi Korban di antaranya adalah (a) Korban pasti memiliki rasa cemas dan kepercayaan diri yang rendah. (b) Korban proaktif meliliki sifat yang lebih kuat secara fisik (c) Korban melakukan pembalasan jika diprovokasi dan merasa dirinya tertekan. Dampak dari kegiatan menyimpang ini bukan hanya bagi korban saja namun juga pada yang melakukan hal tersebut. Pertama, jika dibiarkan atau tidak ditindaklanjuti dengan benar Pelaku bullying tidak akan merubah sikapnya bahkan semakin agresi Pelaku di usia dini rentan terhadap masalah psikolog yang berkepanjangan dan perilaku tersebut jika tidak segera ditangani dengan cepat dan tepat akan beresiko menjadikan anak pada waktu remaja tidak bahagia, dan teman-teman akan merasa takut untuk berteman.

Aktivitas terakhir dari pengabdian ini adalah diseminasi tentang adanya tindakan bullying. Dengan diseminasi diharapkan semua stakeholder di MI Muhammadiyah Bendo bisa melakukan antisipasi dan meminimalkan terjadinya aksi perundungan (bullying).

\section{Daftar Pustaka}

Astuti, Retno. (2013). Meredam Bullying, Jakarta: PT Grasindo Kompas Gramedia.

Brimblecombe N, Evans-Lacko S, Knapp M, King D, Takizawa R, Maugham B \& Arseneault L 2018. Long term economic impact associated with childhood victimisation. Social Science \& Medicine, 208:134141.

https://doi.org/10.1016/j.socscimed.2018.05.014

Crick, N.R. and Grotpeter, J. K. (1995) Relational aggression, gender, and social-psychological adjustment. Child Development, 66:710-722.

Djamal, (2015). Paradigma penelitian Kualitatif, Yogyakarta: Pustaka Belajar.

Hanurawan, Fattah. (2012). Psikologi sosial suatu pengantar, Bandung: PT. Rosdakarya.

Haynie, D. L., Nasel, T., Eitel, P., Crump, A. D., Saylor, K., Yu, K., \& Simons-Morton, B. (2001).Bullies, victims, and bully/victims: Distinct groups of at-risk youth. Journal of Early Adolescence, 21, 29-49.
Hidayatullah, M. Furqon. (2010). Pendidikan Kararakter: Membangun Perdaban Bangsa, Surakarta. Yumma Pustaka.

Huraerah, Abu. (2012). Kekerasan terhadap Anak, Bandung: Nuansa Cendikia.

Indrayani, Sisca (2019). Analisis Perilaku Bullying SiswaSekalah Menengah Atas Al-Azhar 3 Bandar Lampung. Skripi Prodi Bimbingan Konseling, FKIP, Universitas Lampung.

Jan, A., \& Husain, S. (2015). Bullying in Elementary Schools: Its Causes and Effects on Students. Journal of Education and Practice, 6(19), 43-56.

Kemdiknas, (2010). Pembinaan pendidikan Karakter di Sekolah, Jakarta.

Kemdiknas, (2006). Standar Kompetensi Lulusan Satuan Pendidikan, Jakarta

M.E, Raco, J.R. (2010). Metode penelitian Kualitatif jenis Karakteristik dan Keunggulan, Jakarta: PT. Grasindo.

Novalia, Ricca. (2016). Dampak Bullying Terhadap Kondisi Psikososial Anak di Perkampungan Sosial Pingit. Skripsi. Prodi Ilmu Kesejahteraan Sosial, Fakultas Dakwah dan Komunikasi UIN Sunan Kalijaga Yogyakarta.

Owens, L.,Shute, R., \& Slee, P. (2000). "Guess what I just heard": Indirect aggression among Teenage girls in Australia. Aggressive Behavior, 26, 67-83.

Raharjo, ST. (2015). Assessment untuk praktik Pekerjaan Sosial dan Kesejahteraan Sosial, Bandung: Unpad Press.

Santrock, John W. (2011). Masa Perkembangan Anak, Jakarta: Salemba Humanika.

Smit B \& Scherman V (2016). A case for relational leadership and an ethics of care for counteracting bullying at schools. South African Journal of Education, 36(4):Art. \# 1312, 9 pages.

https://doi.org/10.15700/saje.v36n4al312

Undang-undang No. 20 Tahun 2003. Tentang Sistem Pendidikan Nasionala.

Wulandari, Ayu Wangi. (2017). Karakteristik Prilaku dan Korban Bullying Di SMA Negeri 11 Surabaya. Jurnal BK UNESA. Vol. 7 Nomor 2

Zakiyah, Ela Zain., Humaedi, Sahadi., dan Santoso, Meillanny Budiarti. (2017). Faktor-faktor yang Mempengqruhi Remaja dalam Melakukan Bullying. Jurnal Penelitian \& PPM UNPAD ISSN: 2442$448 X V$ ol 4 , No:2. 